Katarzyna A. Kuć-Czajkowska, Justyna Wasil

\title{
Wybory samorządowe w Norwegii. Przykład obywatelskości w ugruntowanej demokracji lokalnej
}

\section{Wprowadzenie}

Norwegia jest jednym z najrzadziej zaludnionych państw Europy kontynentalnej, pod względem gęstości zaludnienia zajmuje przedostatnie miejsce (przed Islandią). Powierzchnię tego kraju - $385252 \mathrm{~km}^{2}$ (w tym tak zwaną Norwegię właściwą, prowincję Svalbard i wyspę Jan Mayen) - zamieszkuje nieco ponad 5,3 mln mieszkańców ${ }^{1}$. Królestwo Norwegii może posłużyć jako przykład państwa o wysokim poziomie zaangażowania mieszkańców w życie publiczne. Norwegowie wykazują się znacznym zainteresowaniem sprawami życia lokalnego, co wynika z ukształtowanej

Katarzyna A. Kuć-Czajkowska (ORCID: 0000-0003-1098-7286) - doktor habilitowana, pracuje na Wydziale Politologii i Dziennikarstwa Uniwersytetu Marii Curie-Skłodowskiej w Lublinie, w Katedrze Administracji Publicznej Instytutu Nauk o Polityce i Administracji. Kontakt: katarzyna.kuc-czajkowska@poczta.umcs.lublin.pl.

Justyna Wasil (ORCID: 0000-0002-5684-9869) - doktor, pracuje na Wydziale Politologii i Dziennikarstwa Uniwersytetu Marii Curie-Skłodowskiej w Lublinie, w Katedrze Administracji Publicznej Instytutu Nauk o Polityce i Administracji. Kontakt: justyna.wasil@poczta.umcs.lublin.pl.

1 Zob. „Rocznik Statystyki Międzynarodowej 2019”, Główny Urząd Statystyczny, Warszawa 2019; M. Dudzicz, Królestwo Norwegii, w: S. Wróbel (red.), Samorząd terytorialny państw europejskich, Wydawnictwo Śląsk, Katowice 2012. 
przez lata kultury politycznej, solidaryzmu społecznego wymuszonego surowymi warunkami klimatycznymi, dążeniem do poprawy jakości życia oraz przekonaniem, że obecność w życiu publicznym pozwala na wywieranie rzeczywistego wpływu na ostateczny kształt decyzji podejmowanych przez władze ${ }^{2}$. Samorząd terytorialny w Norwegii jest uznawany za instytucję, bez której nie może istnieć demokratyczne państwo, stanowi zatem jeden z fundamentów ładu społecznego.

Charakterystyczny dla Norwegii jest północnoeuropejski model samorządu (państwa opiekuńczego) sprowadzający się do odpowiedzialności samorządów za stosunkowo szeroki zakres zadań i usług publicznych, między innymi poprzez realizowanie szeregu usług społecznych, socjalnych i z zakresu ochrony zdrowia, świadczonych we współpracy z organizacjami non-profit ${ }^{3}$. Bliska współpraca oparta na zasadzie wsparcia finansowego i rzeczowego określana jest mianem „nordyckiego modelu uczestnictwa".

W Polsce badania nad samorządem i wyborami lokalnymi w Norwegii są prowadzone bardzo rzadko. Autorem większości opracowań poświęconych systemom politycznym państw skandynawskich, w tym Norwegii, jest Marian Grzybowski ${ }^{5}$. Charakterystykę administracji centralnej i samorządowej tego państwa można znaleźć w pracach Joachima Osińskie-

2 W połowie lat siedemdziesiątych ubiegłego wieku frekwencja w wyborach samorządowych w Norwegii wynosiła ponad 80 proc. Zob. Higher Voter Turnout, Statistics Norway, 22 sierpnia 2014, https:/www.ssb.no/eng/valg/statistikker/kommvalg (dostęp: wrzesień 2014); M. Dudzicz, Królestwo..., s. 484.

3 Zob. L. Rajca, Modele samorzadu terytorialnego, w: idem (red.), Samorzad terytorialny w Europie Zachodniej, Wydawnictwo Elipsa, Warszawa 2010, s. 16.

$4 \quad$ W modelu tym pracownicy socjalni blisko współpracują z wolontariuszami i lokalnymi organizacjami. Znajduje to odzwierciedlenie w strukturze zatrudnienia, gdyż około 20 proc. wszystkich zatrudnionych w Norwegii to pracownicy tego sektora. Zob. J.M. Logo, Civil Society and the Welfare State in Norway - Historical Relations and Future Roles, "Community Development Journal” 2018 nr 53 (3) s. 577-578; Local Government in Norway, Ministry of Local Government and Modernisation, Oslo b.r.w., s. 7.

5 Zob. M. Grzybowski, Organizacje interesów grupowych i ich rola w szwedzkim i norweskim systemie politycznym, „Zeszyty Naukowe Uniwersytetu Jagiellońskiego. Prace z Nauk Politycznych" 1984, t. 21; idem, Systemy konstytucyjne państw skandynawskich, Wydawnictwo Sejmowe, Warszawa 1998; idem, Rzad i administracja rzadowa w monarchiach skandynawskich (Dania - Norwegia - Szwecja), Oficyna Wydawnicza Abrys, Kraków 2001; idem, Norwegia. Zarys systemu ustrojowego, Wydawnictwo Uniwersytetu Jagiellońskiego, Kraków 2015. 
go $^{6}$. Opis samorządu terytorialnego oraz wyborów lokalnych i prowincjonalnych w Norwegii zawiera opracowanie Martyny Dudzicz ${ }^{7}$. Kwestiami związanymi z demokracją bezpośrednią w tym kraju zajmuje się Andrzej $\mathrm{Kubka}^{8}$. W niniejszym artykule, oprócz wyżej wymienionej literatury i aktów prawnych, wykorzystałyśmy dane pochodzące z norweskiego Centralnego Urzędu Statystycznego (Statistisksentralbyrå, SSB).

Naszym celem jest przybliżenie problematyki wyborów samorządowych w Norwegii jako przejawu funkcjonowania ugruntowanej demokracji uczestniczącej. Podejmujemy się próby udzielenia odpowiedzi na następujące pytania badawcze:

- Z czego wynika zaangażowanie mieszkańców w sprawy lokalne, a przede wszystkim udział w wyborach?

- Czy zasady przeprowadzania głosowania i prawa wyborcze wpływają na aktywność wyborczą obywateli?

- Jakie były wyniki i rozkład poparcia politycznego w wyborach samorządowych przeprowadzonych w latach 2011, 2015 i 2019?

6 Zob. J. Osiński, Parlament i rząd w Królestwie Norwegii, Szkoła Główna Handlowa, Warszawa 1994; idem, Doświadczenia samorządu lokalnego w krajach nordyckich a reforma samorzadowa $w$ Polsce, w: P. Dobrowolski (red.), Władza i społeczności lokalne a reforma samorzadowa $w$ Polsce, Wydawnictwo Uniwersytetu Śląskiego, Katowice 1995, s. 133-149; Konstytucja Królestwa Norwegii, tłum. J. Osiński, Wydawnictwo Sejmowe, Warszawa 1996; idem, Problemy aksjologii samorzadności lokalnej w krajach nordyckich $i$ w Polsce, w: B. Nawrot, J. Pokładecki (red.), Samorzad gminny w Polsce. Stan obecny i perspektywy, Wydawnictwo Naukowe Uniwersytetu Adama Mickiewicza, Poznań 1999; idem, Status i funkcjonowanie samorzadu lokalnego w państwach skandynawskich, w: D. Walczak-Duraj (red.), Tradycja i współczesne odmiany samorzadności, „Zeszyty Naukowe Szkoły Wyższej im. Pawła Włodkowica w Płocku” 1999, t. 11.

7 M. Dudzicz, Królestwo... .

8 A. Kubka, Podziaty socjopolityczne w Norwegii w latach 1973-1997, Wydawnictwo Uniwersytetu Gdańskiego, Gdańsk 2004; idem, Metodologiczne aspekty badań zachowań wyborczych w Norwegii, w: A. Antoszewski, A. Dumała, B. Krauz-Mozer, K. Radzik (red.), Teoretyczne i metodologiczne wyzwania badań politologicznych $w$ Polsce, Wydawnictwo Uniwersytetu Marii Curie-Skłodowskiej, Lublin 2009; idem, Partie i systemy partyjne Szwecji, Norwegii i Danii na przełomie XX i XXI wieku, Wydawnictwo Uniwersytetu Gdańskiego, Gdańsk 2009; idem, Demokracja bezpośrednia w Szwecji i Norwegii, w: M. Marczewska-Rytko (red.), Stan i perspektywy demokracji bezpośredniej w Polsce, Wydawnictwo Uniwersytetu Marii Curie-Skłodowskiej, Lublin 2010; idem, Poszukiwanie nowych form demokracji bezpośredniej w krajach skandynawskich, w: M. Marczewska-Rytko (red.), Stan i perspektywy demokracji bezpośredniej we wspótczesnym świecie, Wydawnictwo Uniwersytetu Marii Curie-Skłodowskiej, Lublin 2011; idem, Modele demokracji w Skandynawii, Wydawnictwo Libron, Kraków 2016. 
Artykuł został podzielony na trzy części. W pierwszej omawiamy transformację samorządu terytorialnego oraz zasad przeprowadzania wyborów w Norwegii. W drugiej opisujemy obwiązujące obecnie zasady organizacji i przeprowadzania wyborów, a także podziału mandatów. W trzeciej podejmujemy próbę interpretacji wyników trzech ostatnich wyborów (z lat 2011, 2015 i 2019) z uwzględnieniem frekwencji, poparcia dla poszczególnych partii politycznych oraz płci, wieku, pochodzenia i wykształcenia wyborców.

\section{Historia norweskiego samorządu terytorialnego i praw wyborczych}

Kształtowanie się samorządu terytorialnego w Norwegii rozpoczęło się wraz z przyjęciem 14 stycznia 1837 roku ustawy o charakterze samorządowym - aktu o zarządzie gmin. W ustawie tej zdefiniowano prawa i zadania organów władz oraz wprowadzono nowe rozstrzygnięcia dotyczące zasad organizacji administracji lokalnej. Norwegię podzielono na 355 jednostek szczebla podstawowego (herredskommune - okręg parafialny, parafia, okręg wiejski) i 37 jednostek miejskich (bykommune). Powołane niezależne jednostki administracyjne - gminy - były zarządzane przez organy wyłonione w wyborach powszechnych. Mieszkańcy gmin wiejskich uzyskali prawo wybierania składu instytucji przedstawicielskiej, tzw. representantskap (dzisiejszej rady) i kolegialnego kierownictwa gminy, tzw. formannskap (zarządu). Zasady głosowania w wyborach komunalnych były ograniczone pewnymi cenzusami (w tamtym czasie trudno było mówić o pełnej demokratyzacji życia publicznego). Pełnią praw wyborczych cieszyli się tylko mężczyźni mieszkający w Norwegii od co najmniej pięciu lat, którzy ukończyli 25. rok życia. Ponadto obowiązywały cenzus majątkowy i cenzus stanowiska. Czynne prawo wyborcze mieli urzędnicy administracji państwowej i komunalnej, właściciele i dzierżawcy ziem uprawnych, a także obywatele miast kupieckich dysponujący majątkiem nieruchomym o wartości co najmniej 300 talarów. Bierne prawo wyborcze przysługiwało Norwegom, którzy ukończyli 30. rok życia i zamieszkiwali państwo przez co najmniej 10 lat ${ }^{9}$.

9 Zob. A. Bereza-Jarociński, Zarys dziejów Norwegii, Wydawnictwo Naukowe PWN, Warszawa 1991, s. 151-152; T. Cieślak, Norwegia. Z dziejów XIX i XX wieku, Wydawnictwo Poznańskie, Poznań 1970, s. 24-25; M. Dudzicz, Królestwo..., s. 450-451. 
Oprócz jednostek szczebla podstawowego utworzono jednostki stopnia wyższego - okręgi (amtskommune). Ustalona wówczas liczba 19 okręgów była zmieniana w latach 1866-1972 i ostatecznie wzrosła do $20^{10}$. W 1918 roku nazwę amtskommune (okręg) zastąpiono obowiązującą współcześnie nazwą fylke (prowincja). W unormowaniach z 1837 roku organy władzy w okręgach były zorganizowane w inny sposób niż na poziomie gminnym. Organ zarządzający (amrsformannskap) miał charakter kolegialny. W jego skład wchodzili zarządcy miejscowości z danego okręgu. Pracę tego organu organizował kierownik (amstmann), który - co warto podkreślić - był urzędnikiem państwowym, a nie komunalnym ${ }^{11}$.

Wśród dalszych reform należy wymienić tę z 1896 roku, kiedy to zmianie uległy zasady wyboru zarządu gminnego (formannskap). Bezpośredni sposób wyłaniania, przysługujący mieszkańcom od 1837 roku, został zastąpiony formą pośrednią: przez radę gminy. W 1905 roku wprowadzono kolejne zmiany w prawie wyborczym: zniesiono cenzus majątkowy oraz przyznano prawa wyborcze części kobiet (tym, które ukończyły szkołę podstawową). Pięć lat później nastąpiło zrównanie praw wyborczych kobiet i mężczyzn. Systematycznie wzrastała liczba gmin: z 392 w 1838 roku do najwyższej w historii Norwegii - 744 w 1930 roku ${ }^{12}$.

Niewielka powierzchnia gmin, a ponadto postępujący proces demograficznego starzenia i wyludniania stanowiły przesłanki do przeprowadzenia reformy konsolidacyjnej, tj. połączenia gmin w większe jednostki pod względem powierzchni i liczby ludności. Na mocy ustawy z 12 listopada 1954 roku duże miasta przyłączono do okręgów i zredukowano liczbę gmin z $744^{13}$ do 451 . W wyniku tej reformy zmniejszeniu uległy dysproporcje w świadczeniu usług między gminami, a utworzone jednostki

10 M. Liber, Samorzad miejski w Norwegii na przykładzie Oslo, Bergen i Stavanger, w: S. Wróbel (red.), Samorzad miejski - zadania, instytucje, formy, Wydawnictwo Wyższej Szkoły Bankowej, Poznań - Chorzów 2008, s. 378.

11 M. Dudzicz, Królestwo..., s. 451.

12 Ibidem, s. 452-453; A. Bereza-Jarociński, Zarys dziejów..., s. 235; T. Cieślak, Zarys historii najnowszej krajów skandynawskich, Wydawnictwo Naukowe PWN, Warszawa 1978, s. 161; M. Liber, Samorzad miejski..., s. 377.

13 M. Dudzicz, Królestwo..., s. 454. Tadeusz Cieślak podaje inne dane. Według tego autora w 1960 roku w Norwegii było 750 gmin, a w 1966 roku liczba ta została zredukowana do 460, w tym 47 gmin miejskich i 413 wiejskich. Zob. T. Cieślak, Zarys historii.., s. 431. 
zyskały możliwości efektywniejszego wykorzystania środków z budżetu centralnego oraz dysponowały wyższą pulą dochodów własnych ${ }^{14}$.

Utrzymano dwustopniową strukturę samorządu terytorialnego (gminy i prowincje). Radni do rad gmin byli wybierani metodą reprezentacji proporcjonalnej na czteroletnią kadencję. Wyjątek stanowiły małe gminy, w których obowiązywał system większościowy. W skład rady wchodziło 13-85 członków, a jej kompetencje koncentrowały się wokół: służb publicznych, ochrony zdrowia, usług publicznych, edukacji, transportu i dróg publicznych, uchwalania budżetu, podatków oraz zarządzania gminnym mieniem. Rada gminy wybierała: przewodniczącego rady (który był jednocześnie przewodniczącym zarządu), wiceprzewodniczących rady, członków zarządu, skarbnika, komisje gminne, dyrektora gminy (szefa administracji w gminach powyżej 10 tys. mieszkańców). Do obowiązków zarządu wybieranego w sposób pośredni (przez radę gminy) należał nadzór finansowy i administrowanie gminą. Z kolei na poziomie prowincji organem stanowiącym była rada prowincji (składająca się z przewodniczących rad gmin z obszaru prowincji). Rada wybierała na dwuletnią kadencję spośród swoich członków czteroosobowy zarząd prowincji ${ }^{15}$. Rozproszone przywództwo lokalne i kolektywny sposób podejmowania decyzji, z późniejszym uwzględnieniem parytetów płci w gremiach wykonawczych, jest wyrazem kształtowania samorządu osadzonego w społeczeństwie.

Chociaż reforma konsolidacyjna z 1954 roku oznaczała wymierne korzyści, to nie zakończyła się pełnym sukcesem. Nierozwiązany pozostał problem ograniczonego zakresu autonomii lokalnej. Przedstawiciele organów władzy uskarżali się na ingerowanie państwa w sprawy lokalne (poprzez system dotacji oraz restrykcyjne i nieelastyczne prawo). W tej sytuacji zdecydowano o przeprowadzeniu tak zwanego Eksperymentu Wolnych Gmin i Prowincji. Wraz z przyjętą 1986 roku ustawą status wolnych gmin i prowincji uzyskało 20 gmin i 4 prowincje. Władze jednostek

14 T. Cieślak, Zarys historii..., s. 431; M. Dudzicz, Królestwo..., s. 454; M. Liber, Samorząd miejski..., s. 379; H. Baldersheim, Samorządy lokalne krajów skandynawskich w okresie przejściowym: od wolnych gmin do wolnego wyboru? Nowy program reform samorządowych w państwach skandynawskich, „Samorząd Terytorialny” 1994, nr 1-2, s. 99 i nast.

15 Zob. E.J. Nowacka, Samorząd terytorialny jako forma decentralizacji administracji publicznej, LexisNexis, Warszawa 2010, s. 110-112. 
objęte Eksperymentem zyskały większe możliwości samodzielnego podejmowania decyzji, a także szerszy katalog kompetencji w zakresie formułowania prawa lokalnego ${ }^{16}$. Program realizowano przez cztery lata (1987-1990), a jego celem było stymulowanie rozwoju systemu administracji lokalnej oraz poprawa współpracy między centralnymi i lokalnymi organami władzy. Zakładano, że zredukowanie kontroli ze strony administracji centralnej zapewni przedstawicielom władz samorządowych skuteczniejsze działanie i świadczenie usług. Umożliwienie gminom/prowincjom zwolnień z niektórych przepisów i zaproponowanie alternatywnych rozwiązań pozwoliło organom władzy centralnej na zorientowanie się, w jakich dziedzinach ustawodawstwo ogranicza działalność samorządów.

Eksperyment Wolnych Gmin i Prowincji przyczynił się do zmiany relacji państwo-samorząd. Władze samorządowe zyskały większe możliwości samodzielnego podejmowania decyzji, a także kompetencje w zakresie formowania prawa dotyczącego problemów lokalnych. Bezpośrednim efektem Eksperymentu było uchwalenie Ustawy o samorzadzie z 1992 roku $^{17}$, gwarantującej gminom i prowincjom szerszą autonomię organizacyjną.

Współczesny samorząd terytorialny Norwegii funkcjonuje na podstawie ustawy z 1992 roku, która było kilkakrotnie zmieniana (w latach $2005^{18}, 2012^{19}, 2014^{20}$ i $2019^{21}$ ). Oprócz wspomnianej ustawy organizację i funkcjonowanie jednostek samorządowych regulują przepisy komunalnego prawa ustrojowego i administracyjnego prawa materialnego ${ }^{22}$. Trzeba dodać, że norweski samorząd ma umocowanie prawne jedynie

16 M. Dudzicz, Królestwo..., s. 454; W. Nowiak, Stopniowe usamodzielnianie finansowe społeczności lokalnych Norwegii. Element upodmiotowienia społeczeństwa dobrobytu, w: D. Walczak-Duraj (red.), Tradycja..., s. 141.

17 Local Government Act no. 107 of 25 September 1992, Government.no, 15 listopada 2012, https://www.regjeringen.no/globalassets/upload/krd/vedlegg/komm/internasjonalt/local_government_act.pdf (dostęp: listopad 2020); W. Nowiak, Stopniowe usamodzielnianie..., s. 141; M. Liber, Samorzad miejski..., s. 380-381.

18 Local Government Act no. 107 of 25 September 1992, ze zmianami z 7 stycznia 2005 roku.

19 Ibidem, ze zmianami z 1 lipca 2012 roku.

20 W 2014 roku zaczęła być wprowadzana reforma łączenia gmin.

21 Local Government Act 2001 Revised, updated to 16 April 2019, http://revisedacts.lawreform.ie/ eli/2001/act/37/revised/en/pdf?annotations=true (dostęp: listopad 2020).

22 Zob. szerzej: M. Dudzicz, Królestwo..., s. 456. 
w ustawach. Konstytucja Królestwa Norwegii z 1814 roku nie zawiera uregulowań w zakresie jego organizacji ${ }^{23}$.

W Norwegii obowiązuje dwustopniowy podział terytorialny. Na poziomie regionalnym są to prowincje $\mathrm{e}^{24}$ (fylke), a na poziomie lokalnym gminy (kommune). Obie jednostki objęto reformami konsolidacyjnymi. Łączenie gmin zostało zatwierdzone przez parlament (Storting) 9 czerwca 2015 roku. Reformę przeprowadzono w kilku etapach: w 2015 roku w Norwegii było 430 gmin. Do 1 stycznia 2017 roku ich liczba została zmniejszona do 426, do 1 stycznia 2018 roku - do 422, a na początku 2020 roku - do 356. W wyniku ustawy przyjętej przez parlament 8 czerwca 2017 roku łączeniu poddano prowincje, zmniejszając ich liczbę z 19 do 11 od 1 stycznia 2020 roku $^{25}$. Wybory samorządowe przeprowadzone 9 września 2019 roku były pierwszymi po konsolidacji gmin i prowincji, w których wyłoniono przedstawicieli organów władzy do nowo ukształtowanego podziału terytorialnego.

Mimo że „dążono do tego, aby reforma nie była zarządzana centralnie, ale by społeczności lokalne łączyły się z własnej woli”26, przeprowa-

23 „Przepisy konstytucyjne w krajach nordyckich odnoszą się wstrzemięźliwie do struktur samorządu terytorialnego. Jak pisze Marian Grzybowski, u źródeł takiego nastawienia tkwi przekonanie, że wspólnoty samorządowe nie są częścią aparatu państwowego, podczas gdy funkcją konstytucji jest regulowanie struktury i zasad funkcjonowania państwa oraz pozycji obywatela w państwie”. M. Grzybowski, Systemy..., s. 131. Zob. też T. Kaczmarek, Struktury terytorialno-administracyjne i ich reformy w krajach europejskich, Wydawnictwo Naukowe Uniwersytetu Adama Mickiewicza, Poznań 2005, s. 50.

24 W literaturze można spotkać różne nazwy norweskich jednostek ponadlokalnych (regionalnych): prowincje, okręgi, hrabstwa, dystrykty, powiaty, regiony, województwa. Na określenie ponadlokalnego poziomu samorządu konsekwentnie stosujemy nazwę "prowincja”.

25 Są to: Oslo, Rogaland, Møre og Romsdal, Nordland, Viken, Innlandet, Vestfold og Telemark, Agder, Vestland, Trøndelag, Troms og Finnmark. Na temat potrzeby utworzenia większych samorządów dyskutowano od wczesnych lat dziewięćdziesiątych ubiegłego wieku. Argumentowano, że mniejsza liczba gmin będzie oznaczać między innymi niższe wydatki na administrację, zapewnienie lepszej jakości opieki społecznej mieszkańcom, większe korzyści skali, łatwiejsze zarządzanie, a także możliwość rozdysponowywania większej puli środków finansowych. Jak szacowano, będzie to skutkowało likwidacją stanowisk w organach władzy samorządowej i zmniejszeniem liczby urzędników o 17 proc. Zob. M. Berbeć, Historyczne zmiany na mapie Norwegii: rząd połaczy część norweskich gmin... sita, Moja Norwegia. Portal Polaków w Norwegii, 2 czerwca 2017, https://www.mojanorwegia.pl/aktualnosci/historyczne-zmiany-na-mapienorwegii-rzad-polaczy-czesc-norweskich-gmin-sila-12891.html (dostęp: listopad 2020).

26 N. Berglund, Small Towns Want to Stay That Way, NewsinEnglish.no, 24 maja 2016, https:// www.newsinenglish.no/2016/05/24/residents-reject-municipal-mergers/ (dostęp: listopad 
dzenie konsolidacji w jedenastu gminach spotkało się z oporem władz samorządowych ${ }^{27}$. W praktyce reforma regionalna została określona jako „najpotężniejsze narzędzie centralizacji, z jakim kiedykolwiek spotkaliśmy się w Norwegii" (the biggest centralization measure we've ever seen in Norway) ${ }^{28}$. Przedstawiciele administracji państwowej twierdzili, że reforma jest częścią decentralizacji, natomiast samorządowcy - zmuszeni do działań konsolidacyjnych - podnosili argument utraty samodzielności i tożsamości jednostek samorządu, a także wyrażali obawy o zdominowanie przez „silniejszą” z łączących się jednostek.

Należy się zgodzić z twierdzeniem Martyny Dudzicz, iż wysoki udział Norwegów w życiu publicznym wynika z sięgających średniowiecza korzeni instytucji samorządu. Ówczesne wspólnoty lokalne stanowiły organizację, której zadaniem była pomoc najbardziej potrzebującym. Pomoc ta stanowiła wyraz solidarności międzyludzkiej w związku z trudnymi warunkami klimatycznymi. Historia i tradycja norweskiego samorządu stanowi zatem źródło dzisiejszych wspólnotowych zachowań mieszkańców ${ }^{29}$.

\section{Norweskie prawo wyborcze}

Zasady organizacji i przeprowadzania wyborów samorządowych w Norwegii uregulowano w ustawie z 28 czerwca 2002 roku o przedstawicielach ludności ${ }^{30}$. Szczegółowe zasady organizacji i przeprowadzania wyborów

2020). Zob. też idem, Counties Will be Forced to Merge, NewsinEnglish.no, 24 sierpnia 2018, https://www.newsinenglish.no/2018/09/24/counties-will-be-forced-to-merge/ (dostęp: listopad 2020).

27 Szczególnie komentowana była decyzja rządu o połączeniu gmin Flora i Vågsøy, gdyż reforma nie objęła gminy Bremanger, położonej między tymi gminami (rząd postanowił nie działać wbrew woli jej władz). W związku z tym obszar nowej gminy jest podzielony na dwie części, Zob. M. Berbeć, Historyczne zmiany...; Gminy nie chca się taczyć, ale... rzad może je do tego zmusić, Moja Norwegia. Portal Polaków w Norwegii, 8 września 2016, https://www.mojanorwegia.pl/polityka/gminy-nie-chca-sie-laczyc-ale-rzad-moze-je-do-tego-zmusic-11864.html (dostęp: listopad 2020).

28 N. Berglund, Counties... .

29 M. Dudzicz, Królestwo..., s. 485.

30 The Representation of the People Act (ustawa o przedstawicielach ludności), pełna nazwa: Act no. 57 of 28 June 2002 relating to parliamentary and local government elections, Government.no, 14 marca 2019, https://www.regjeringen.no/en/dokumenter/election-act/id2632557/ (dostęp: listopad 2020). 
określone są też w statucie każdej z gmin i prowincji. W związku z organizacją wyborów samorządowych w 2019 roku (po reformie konsolidacyjnej) przyjęto odrębne regulacje dotyczące wyborów prowincjonalnych ${ }^{31}$ i gminnych ${ }^{32}$.

Zgodnie z ordynacją reprezentanci rad gmin i rad prowincji wyłaniani są w sposób bezpośredni na czteroletnią kadencję. Głosowanie jest przeprowadzane w połowie kadencji parlamentu. Wybory odbywają się (zwyczajowo) w drugi poniedziałek września. Ich datę wyznacza król. Władze samorządowe mogą jednak zdecydować o głosowaniu w niedzielę poprzedzającą wyznaczony przez króla poniedziałek wyborczy. Ponadto wyborcy mogą skorzystać z możliwości głosowania przed dniem wyborów. Uprawnieni do głosowania w Norwegii i za granicą mogą oddawać głosy od 10 sierpnia (wyborcy prowincji Svalbard i wyspy Jan Mayen od 1 lipca) do ostatniego piątku poprzedzającego dzień wyborów ${ }^{33}$. W wyborach w 2011 roku umożliwiono głosowanie za pośrednictwem Internetu.

Do udziału w głosowaniu do rad gmin i rad prowincji uprawnieni są obywatele norwescy cieszący się pełnią praw wyborczych, którzy nie później niż 31 grudnia w roku wyborczym ukończą 18 lat. Warto dodać, iż w 2011 roku w wyborach samorządowych mogły po raz pierwszy głosować osoby, które ukończyły 16 . rok życia ${ }^{34}$. Podobnie w wyborach w 2015 roku w dwudziestu gminach stworzono możliwość głosowania 16- i 17-latkom. Uprawnione do udziału w wyborach są również osoby nie mające norweskiego obywatelstwa, ale mieszkające co najmniej 3 lata w Norwegii, o ile zarejestrowały się w spisie mieszkańców do 31 marca roku wyborczego. Podobnie obywatele państw nordyckich nabywają prawa wyborcze w dniu, w którym zostali zarejestrowani w spisie ludności jako stali mieszkańcy Norwegii ${ }^{35}$.

31 Regulations on the Implementation of the County Council Elections in 2019, Ministry of Local Government and Modernisation, Oslo, 2 maja 2018 - 31 grudnia 2019.

32 Ibidem.

33 M. Dudzicz, Królestwo..., s. 457.

34 The Trial of Reducted Voting Age to 16 for the Local Election in 2015, Statistics Norway, b.d., http://www.regjeringen.no/en/dep/kmd/information-campaigns/election_portal/trial-of-reduced-voting-age-to-16-for-th.html?regj_oss=2\&id=581646 (dostęp: sierpień 2014).

35 M. Dudzicz, Królestwo..., s. 457-458. 
Osoby uprawnione do głosowania, w tym imigranci, mogą jednocześnie kandydować w wyborach do rad. Biernego prawa wyborczego są pozbawieni: gubernator prowincji ${ }^{36}$ i jego zastępca oraz każda osoba, która we władzach gminy/prowincji jest przewodniczącym/zastępcą organu wykonawczego, kierownikiem działu administracji, sekretarzem rady gminy/prowincji, osobą odpowiedzialną za księgi rachunkowe lub audyt. Ponadto, zgodnie z art. 53 Konstytucji Królestwa Norwegii, odnoszącym się do każdego rodzaju głosowania, prawa wyborcze mogą zostać odebrane (w tym czasowo) ze względu na szereg czynników związanych z łamaniem prawa krajowego (na przykład popełnienie przestępstwa umyślnego, oszustwa wyborczego czy dopuszczenia się zdrady kraju) ${ }^{37}$.

Rady gmin i prowincji mają swobodę wyboru między dwoma rozwiązaniami ustrojowymi: systemem „tradycyjnym” albo parlamentarną formą władzy lokalnej. Od dokonanego wyboru zależą kształt i uprawnienia organu wykonawczego. W większości gmin i prowincji stosowany jest system tradycyjny. Jego istotą jest zdecydowana dominacja organu stanowiącego (rady) nad pozostałymi organami. W modelu tym rada ma kompetencje uchwałodawcze i wykonawcze. Istotną cechą jest brak wyraźnie wyodrębnionego organu wykonawczego. W większych miastach stosuje się natomiast model parlamentarny. Jest to model dualistyczny, w którym obok siebie występują, z wyraźnie oddzielonymi kompetencjami, rada i wybierany przez nią zarząd $\mathrm{d}^{38}$.

W ustawie samorządowej została określona minimalna liczba wybieranych przedstawicieli organu uchwałodawczego (radnych). W gminach o populacji poniżej 5 tys. w skład rady wchodzi przynajmniej 11 członków, w gminach/prowincjach o populacji 5-10 tys. - 19 członków, o populacji

36 Gubernator prowincji to reprezentant władzy centralnej, który z urzędu lub na wniosek trzech członków rady gminy kontroluje legalność decyzji podjętych przez radę gminy. Jest strażnikiem praw obywatelskich, ma prawo wglądu w decyzje lokalne odnośnie do praw każdej osoby w dziedzinie ochrony zdrowia, usług społecznych, edukacji, budownictwa, planowania. Może zmienić decyzję na korzyść konkretnej osoby. Local Government in Norway, Ministry of Local Government and Regional Development, Oslo 2008, s. 21.

37 Konstytucja Królestwa Norwegii z 17 maja 1814 roku z późniejszymi zmianami. Zob. Konstytucja Królestwa... .

38 Szerzej: M. Dudzicz, Królestwo..., s. 471-478; E.J. Nowacka, Samorzad..., s. 112-115. 
10-50 tys. - nie mniej niż 27, o populacji 50-100 tys. - nie mniej niż 35, a o populacji powyżej 100 tys. - nie mniej niż 43. Decyzję w sprawie zmiany (to znaczy zwiększenia minimalnej liczby radnych) podejmuje rada zainteresowanej gminy/prowincji. W praktyce rady dość często decydują się na zwiększenie liczby osób w organie stanowiącym.

Radni są wyłaniani w wyborach powszechnych, równych, bezpośrednich, w głosowaniu tajnym, w wielomandatowych okręgach wyborczych. Zarejestrowane partie i inne lokalne komitety przygotowują listy wyborcze. Na liście musi się znaleźć minimum siedmiu kandydatów, a maksymalnie lista może zawierać liczbę kandydatów zgodną z liczbą wybieranych przedstawicieli z nie więcej niż sześcioma dodanymi nazwiskami.

Wyborcy mogą dokonywać zmian na listach. W wyborach na poziomie prowincji prawo to ogranicza się do zmiany kolejności nazwisk kandydatów na liście (wyborca zmienia tę kolejność poprzez umieszczenie obok nazwiska kandydata odpowiedniego numeru) lub wykreślenia nazwiska jednego $\mathrm{z}$ kandydatów ${ }^{39}$. W głosowaniach do rady gminy wyborcy mogą do preferowanej przez siebie listy dodać kandydatów z pozostałych komitetów wyborczych. Oznacza to, że wyborca nie ogranicza się do osobistego poparcia kandydatów z preferowanej przez siebie listy, a głos może przenieść na personalnie wskazanych kandydatów z innych list (poprzez dopisanie ich nazwisk na dole karty do głosowania). Liczba głosów oddanych na „obce” listy jest ograniczona w zależności od liczby mandatów obsadzanych w konkretnych wyborach. Wyborcy mogą oddać swój głos w ten sposób na minimum pięciu kandydatów, maksymalnie zaś liczba ta nie powinna przekroczyć jednej czwartej liczby mandatów do obsadzenia. Głosy oddane na kandydatów spoza głównej listy zmniejszają pulę przysługującą danemu komitetowi. Dopiero w ten sposób skalkulowane wyniki głosowania na poszczególne listy stanowią podstawę do rozdziału mandatów ${ }^{40}$.

39 System głosowania porządkującego pozwala wyborcy na wyrażenie preferencji poprzez uszeregowanie partii. Zob. M. Dudzicz, Królestwo..., s. 458.

40 Act no. 57 of 28 June 2002 relating to...; M. Dudzicz, Królestwo..., s. 458-459; D. Sześciło, J. Jakubek-Lalik, Zróżnicowanie systemów wyborczych w wyborach lokalnych w Europie, w: J. Wojnicki (red.), Europejskie modele samorzadu terytorialnego. Stan obecny i perspektywy, Oficyna Wydawnicza ASPRA-JR, Warszawa 2014, s. 271. 
Podział mandatów jest proporcjonalny w stosunku do liczby głosów oddanych na daną listę. W wyborach gminnych możliwe jest głosowanie większościowe (w sytuacji, gdy zarejestrowano tylko jedną listę). Liczba kandydatów na liście nie może być wyższa od liczby wybieranych radnych. Mandat otrzymuje ten z kandydatów, który uzyska większą liczbę głosów. Jeśli dwóch kandydatów otrzyma taką samą liczbę głosów, o wyborze decyduje losowanie ${ }^{41}$.

Szczególne zasady dotyczą też podziału mandatów wewnątrz danej listy. Obliczanie wyników głosowania przebiega w dwóch etapach. W pierwszym ustala się, ile miejsc w radzie zdobyła dana lista. Mandaty rozdziela się między poszczególne komitety stosując metodę Sainte-Laguë’a z pierwszym dzielnikiem 1,4. Jeżeli liczba mandatów zdobytych przez dany komitet wyborczy przewyższa liczbę ubiegających się o mandat z danej listy, to mandaty zwyżkowe są rozdzielane między pozostałe partie. Następnie określa się, który z kandydatów z danej listy uzyskuje mandat. W wyborach do rad prowincji w pierwszej kolejności mandaty otrzymują kandydaci, którzy uzyskali więcej niż 8 proc. głosów imiennych spośród wszystkich głosów oddanych na daną listę, w kolejności odpowiadającej liczbie oddanych na nich głosów. Pozostałe mandaty są rozdzielane między kandydatów zgodnie z zajmowanym miejscem na liście. W przypadku wyborów na poziomie gminnym istnieje możliwość uprzywilejowania pewnej grupy kandydatów przez komitet wyborczy. Dotyczy to osób ubiegających się o mandat z najwyższych pozycji na liście. Kandydaci, których nazwiska na karcie do głosowania są wyróżnione pogrubionym drukiem uzyskują premię w wysokości 25 proc. głosów oddanych na całą listę. W zależności od liczby mandatów do obsadzenia partia może udzielić dodatkowego poparcia określonej liczbie kandydatów odpowiadającej liczbie wybieranych radnych (przy wyborze 11-23 radnych nie więcej niż czterem kandydatom, przy wyborze 25-53 radnych nie więcej niż sześciu, a przy wyborze 55 i więcej radnych nie więcej niż dziesięciu). Przy rozdzielaniu mandatów w pierwszej kolejności uwzględnia się kandydatów preferowanych przez partię, a następnie nazwiska osób, na które zostały oddane głosy imiennie. Jeśli w obu 
przypadkach liczba głosów jest równa, mandat uzyskuje kandydat zajmujący wyższą pozycję na liście ${ }^{42}$.

Podsumowując, należy stwierdzić, że system wyborczy do rad samorządowych w Norwegii opiera się na szczególnych zasadach. W pierwszym etapie uprawniony do głosowania obywatel głosuje na listę wyborczą (partii politycznej bądź inną zgłoszoną przez uprawnione podmioty). Wyborca może ograniczyć akt głosowania do tego etapu albo ma możliwość stworzenia własnej listy kandydatów: w przypadku wyborów prowincjonalnych - poprzez zmianę kolejności nazwisk kandydatów na liście do głosowania, a w przypadku wyborów gminnych - poprzez zaznaczenie na preferowanej przez siebie liście nazwisk kandydatów, którym udziela osobistego poparcia oraz dodatkowo dopisanie na dole karty do głosowania nazwisk kandydatów z innych list wyborczych (wówczas jednak głos zostanie przeniesiony na tę partię i może to wpłynąć na rozkład mandatów $)^{43}$.

O zaangażowaniu mieszkańców w sprawy lokalne decyduje wysoki poziom wykształcenia społeczeństwa (Norwegowie są jednym z najlepiej wykształconych narodów w Europie), co przekłada się na postawy obywatelskie (obywatelski obowiązek udziału w wyborach) ${ }^{44}$. Bezpośredni wpływ na poziom partycypacji wyborczej ma też termin głosowania (w Norwegii istnieje możliwość głosowania $\mathrm{z}$ wyprzedzeniem, przed dniem wyborów). Czynnikiem umożliwiającym zwiększenie frekwencji jest również wskazanie preferowanego kandydata na listach wyborczych albo tworzenie własnej listy. Dzięki temu wybory stają się bardziej spersonalizowane oraz zapewniają większą identyfikację obywatela z nazwiskiem kandydata.

42 Ibidem; M. Dudzicz, Królestwo..., s. 458-459; M. Liber, Samorzad..., s. 390.

43 Charakterystyczne dla państw skandynawskich jest to, że razem z radnymi wybierana jest grupa ich zastępców. Zasady wyboru i podziału mandatów dla zastępców radnych są identyczne jak zasady przyjęte dla radnych. Zob. D. Sześciło, J. Jakubek-Lalik, Zróżnicowanie..., s. 271-272; M. Zych, Lokalne wybory po norwesku, czyli jak i gdzie oddać swój głos, Moja Norwegia. Portal Polaków w Norwegii, 27 sierpnia 2019, https://www.mojanorwegia.pl/polityka/ lokalne-wybory-po-norwesku-czyli-jak-i-gdzie-oddac-swoj-glos-wybory-2019-16194.html (dostęp: listopad 2020).

44 Most Nominees Are Men above 40, Statistics Norway, 1 lipca 2011, http://www.ssb.no/en/valg/ statistikker/kfvalgkand (dostęp: listopad 2020). 


\section{Wyniki wyborów z lat 2011, 2015 i 2019}

\section{Frekwencja}

Widocznym przejawem obywatelskości, odzwierciedlającym aktywność polityczną i stan demokracji lokalnej, jest rejestrowana frekwencja wyborcza. Norwegowie charakteryzują się dość wysokim poziomem partycypacji wyborczej. Świadczy o tym między innymi udział w wyborach samorządowych na poziomie około 60 proc. $^{45}$. Analizie poddałyśmy wyniki trzech ostatnich lat wyborczych, to znaczy głosowań z 12 września 2011 roku, 14 września 2015 roku i 9 września 2019 roku. Frekwencja w wyborach z 2011 roku wyniosła na poziomie gminnym 64,2 proc., a na poziomie prowincjonalnym - 59,9 proc. W Norwegii zamieszkuje około 386,7 tys. imigrantów uprawnionych do głosowania, z których niemal połowa pochodzi z Afryki i Azji. W 2011 roku frekwencja wyborcza w tej grupie wyniosła około 10 proc. ${ }^{46}$. W tym samym roku z możliwości głosowania przed datą wyborów lub niebezpośrednio w lokalu wyborczym (na przykład w formie elektronicznej) skorzystało 22,2 proc. wyborców ${ }^{47}$.

45 M. Dudzicz, Królestwo..., s. 459, 462.

46 Norwegowie chętniej głosowali w wyborach władz gminnych niż prowincjonalnych. Najwyższy odsetek głosujących odnotowano w gminie Fedce (86,4 proc.), najniższy - w gminie Lebesby (54,2 proc.). Biorąc pod uwagę poziom ponadgminny, najchętniej głosowali mieszkańcy Oslo (65,4 proc.), a najmniej osób zdecydowało się na udział w wyborach w prowincji Østfold (55,6 proc.). Zob. Municipal Council Elections and County Council Election 1999-2011. Percentage Voter Turnout in Municipalities with e-Elections, Statistics Norway, 11 listopada 2011, http://www. ssb.no/a/english/kortnavn/kommvalg_en/tab-2011-11-04-13-en.html (dostęp: listopad 2020); Higher Voter...; 10 per cent of Eligible Voters Have Immigrant Background, Statistics Norway, 24 sierpnia 2016, http://www.ssb.no/en/valg/statistikker/stemmerettkomm (dostęp: sierpień 2014).

47 Istniała możliwość głosowania z wyprzedzeniem, tj. od 10 sierpnia do 9 września 2011 roku, natomiast w okręgach wyborczych zlokalizowanych poza granicami państwa - w Svalbard i Mayen - od 1 lipca (The Trial...). Ponadto w dwudziestu gminach został wprowadzony program pilotażowy umożliwiający głosowanie ludziom młodym, od 16. roku życia, a w dziesięciu gminach (Bodø, Bremerton, Drammen, Hammerfest, Mandal, Radøy, Re, Tynset, Vefsn i Ålesund) umożliwiono głosowanie drogą elektroniczną. Zob. J. Barrat Esteve, B. Goldsmith, J. Turner, Speed and Efficiency of the Vote Counting Process. Norwegian e-Vote Project, The International Foundation for Electoral Systems (IFES), Washington D.C., lipiec 2012, s. 6, dostępne na: http://www.regjeringen.no/upload/KRD/Prosjekter/e-valg/evaluering/Topic4_Assessment. pdf (dostęp: listopad 2020); H. Baldersheim, J. Saglie, S. Bock Segaard, Internet Voting in Norway 2011: Democratic and Organisational Experiences, Den XXI Nordiske Kommuneforskingskonferansen, Universitetet i Oslo, Oslo 2012; Municipal Council... . 
W głosowaniu w 2015 roku frekwencja na poziomie gminnym wyniosła 59,9 proc., a na poziomie prowincji - 55,8 proc., wśród kobiet - 62 proc., a wśród mężczyzn - 57 proc. W grupie osób z wyższym wykształceniem oscylowała wokół 75 proc., a z wykształceniem średnim - 61 proc. Najwyższa frekwencja (76 proc.) została odnotowana wśród wyborców w przedziale wiekowym 67-79 lat. W głosowaniu przeprowadzonym w 2019 roku frekwencja była najwyższa w porównaniu z poprzednimi wyborami, gdyż wyniosła na poziomie gminnym 64,5 proc., a na poziomie prowincji 59,7 proc. Wyższą frekwencję, podobnie jak w poprzednich wyborach samorządowych, odnotowano wśród kobiet (67 proc.) niż wśród mężczyzn (62 proc.). W grupie osób z wyższym wykształceniem frekwencja oscylowała wokół 79 proc., a z wykształceniem średnim - 66 proc. Najwyższa frekwencja, podobnie jak w elekcji z 2015 roku, została odnotowana wśród wyborców w przedziale wiekowym $67-79$ lat (79 proc.) $)^{48}$.

Aktywność wyborcza jest wynikiem postrzegania istotności wyborów przez obywatela. Prawdopodobnie po reformie konsolidacyjnej większa liczba Norwegów była zainteresowana zagłosowaniem na swojego przedstawiciela (zwłaszcza do rady gminy) i to spowodowało wzrost frekwencji w wyborach z 2019 roku. Nie bez znaczenia jest też przyswojenie wzorca zachowań i zainteresowań. W Norwegii najchętniej głosują osoby w wieku 67-79 lat, które mają większe doświadczenie życiowe, wiedzę o współczesnym świecie, wykazują się większą odpowiedzialnością za kształtowanie dobra ogólnego oraz są lepiej sytuowane ekonomicznie ${ }^{49}$.

\section{Poparcie dla partii politycznych}

Partie polityczne, traktowane jako subkategoria organizacji pozarządowych w Norwegii, mają za zadanie transmisję oczekiwań i potrzeb mieszkańców do przedstawicieli organów władzy ${ }^{50}$. We wszystkich analizowanych wyborach

48 Electoral Turnout, Statistics Norway, 8 października 2019, https://www.ssb.no/en/valg/statistikker/valgdeltakelse (dostęp: listopad 2020).

49 Zob. J. Wasil, Czynniki kształtujace frekwencję wyborcza, w: K. Kuć-Czajkowska, K. Efner (red.), Społeczeństwo obywatelskie Lublina $i$ Wrocławia - studia przypadków, Wydawnictwo Uniwersytetu Marii Curie-Skłodowskiej, Lublin 2013, s. 58-61.

50 J. Saglie, K.H. Sivesind, Civil Society Institutions or Semi-public Agencies? State Regulation of Parties and Voluntary Organizations in Norway, , Journal of Civil Society” 2018, t. 14, nr 4, s. 292. 
(z lat 2011, 2015 i 2019) zwycięzcą była Partia Pracy z poparciem 32 proc. w 2011 roku, 33 proc. w 2015 roku, do znacznego odpływu elektoratu w 2019 roku i wyniku na poziomie 24 proc. (tabela 1). Na drugim miejscu znalazła się Partia Konserwatywna (28 proc. głosów w 2011 roku, 23 proc. w 2015 roku i 20 proc. w 2019 roku). Trzecie miejsce należało do Partii Postępu, w przypadku której też można zaobserwować systematyczny odpływ elektoratu (z 11 proc. w 2011 roku, 10 proc. w 2015 roku, do 8 proc. w 2019 roku).

Tabela 1. Poparcie dla największych partii politycznych w wyborach samorządowych w Norwegii w latach 2011, 2015 i 2019 (w proc.)

\begin{tabular}{|l|c|c|c|c|c|c|}
\hline \multirow{2}{*}{ Nazwa partii politycznej } & \multicolumn{5}{|c|}{ Wybory (rok) } \\
\cline { 2 - 7 } & \multicolumn{2}{|c|}{2011} & \multicolumn{2}{c|}{2015} & \multicolumn{2}{c|}{2019} \\
\cline { 2 - 7 } & gminne & $\begin{array}{l}\text { prowin- } \\
\text { cjonalne }\end{array}$ & gminne & $\begin{array}{c}\text { prowin- } \\
\text { cjonalne }\end{array}$ & gminne & $\begin{array}{c}\text { prowin- } \\
\text { cjonalne }\end{array}$ \\
\hline $\begin{array}{l}\text { Arbeiderpartiet } \\
\text { (Partia Pracy) }\end{array}$ & 31,7 & 32,2 & 33,0 & 33,6 & 24,8 & 24,2 \\
\hline $\begin{array}{l}\text { Fremskrittspartiet } \\
\text { (Partia Postępu) }\end{array}$ & 11,4 & 11,8 & 9,5 & 10,3 & 8,2 & 8,6 \\
\hline $\begin{array}{l}\text { Høyre } \\
\text { (Partia Konserwatywna) }\end{array}$ & 28,0 & 27,6 & 23,2 & 23,4 & 20,1 & 20,3 \\
\hline $\begin{array}{l}\text { Kristelig Folkeparti } \\
\text { (Chrześcijańska Partia } \\
\text { Ludowa) }\end{array}$ & 5,6 & 5,8 & 5,4 & 5,6 & 4,0 & 4,1 \\
\hline $\begin{array}{l}\text { Senterpartiet } \\
\text { (Partia Centrum) }\end{array}$ & 6,7 & 6,3 & 8,5 & 8,0 & 14,4 & 14,5 \\
\hline $\begin{array}{l}\text { Sosialistisk Venstreparti } \\
\text { (Partia Socjalistyczna) }\end{array}$ & 4,1 & 4,3 & 4,1 & 4,0 & 6,1 & 6,0 \\
\hline Venstre (Partia Liberalna) & 6,3 & 5,7 & 5,5 & 5,0 & 3,9 & 3,5 \\
\hline $\begin{array}{l}\text { Miljøpartiet De Grønne, } \\
\text { MDG (Zieloni) }\end{array}$ & - & - & 4,2 & 5,0 & 6,8 & 7,6 \\
\hline Rødt (Lewica) & - & - & 2,0 & 2,2 & 2,2 & 3,8 \\
\hline $\begin{array}{l}\text { Folkeaksjonen Nei til } \\
\text { mer bompenger (Nie dla } \\
\text { Opłat Drogowych) }\end{array}$ & - & - & - & - & 2,4 & 3,4 \\
\hline
\end{tabular}

Źródło: Opracowanie własne na podstawie Higher Voter Turnout, Statistics Norway, 22 sierpnia 2014, https://www.ssb.no/eng/valg/statistikker/kommvalg (dostęp: wrzesień 2014); Samanstilt Resultat for Kommunevalet, 9 września 2014, http://www.nrk.no/valg2011/valgresultat/ (dostęp: listopad 2020); Valg, Count for Norway, Valg, 13 października 2015, https://www. valgresultat.no/?type =fy\&year=2015 (dostęp: listopad 2020); Municipal and County Council Election, Executive Committee of Local Council and Chairman Election, Statistics Norway, 16 stycznia 2020, https://www.ssb.no/en/valg/statistikker/kommvalgform (dostęp: listopad 2020). 
Współrządząca Norwegią Partia Konserwatywna uzyskała w 2019 roku najsłabszy wynik w wyborach lokalnych od szesnastu lat (20 proc.). Tylko w porównaniu z rokiem 2015 ugrupowanie to straciło 3 pkt. proc. Na Partię Konserwatywną oraz jej rządowych koalicjantów - Liberałów, Chrześcijańskich Demokratów i Partię Postępu - zagłosowało łącznie 36 proc. wyborców (o 8 pkt. proc. mniej). Partia Postępu straciła w skali kraju 1,2 pkt. proc. poparcia i jest to najniższy wynik wyborczy ugrupowania w prowincjach od lat dziewięćdziesiątych ubiegłego wieku. Notowania Chrześcijańskiej Partii Ludowej oraz Partii Liberalnej zmniejszyły się odpowiednio o 1,4 i 1,6 pkt. proc., a obie partie osiągnęły wynik w okolicach 4 proc. Poparcie utraciła też główna siła opozycyjna - Partia Pracy, uzyskując 24 proc. głosów (o 8 pkt. proc. mniej niż w 2015 roku). W porównaniu z wyborami z 2015 roku więcej głosów zdobyła agrarna Partia Centrum, która zyskała miano zwycięzcy wyborów 2019 roku, gdyż uzyskała najwyższy wzrost poparcia (o 6 pkt. proc. w porównaniu z rokiem 2015). Ponadto $\mathrm{z}$ rekomendacji tego ugrupowania mandat uzyskała najwyższa w skali Norwegii grupa burmistrzów gmin. Partia cieszy się poparciem elektoratu poza dużymi ośrodkami, a norweski system wyborczy premiuje takie ugrupowania przy przeliczaniu głosów ${ }^{51}$. Za zwycięzców wyborów 2019 roku uważani są też Zieloni, którzy otrzymali 6,8 proc. głosów. W Oslo wynik Zielonych był jeszcze wyższy i oscylował wokół 15,2 proc. Dość wysoki odsetek głosów dla tej partii wiąże się z tendencjami obserwowanymi w krajach Europy Zachodniej, gdzie ugrupowania proekologiczne zyskują wyborców, głównie w dużych miastach. Najniższy w historii wynik w wyborach lokalnych uzyskała Partia Pracy (24 proc. głosów). Niski odsetek poparcia partia ta zanotowała już w wyborach z 2003 roku (27 proc.). W porównaniu z wyborami z 2015 roku. Partia Pracy straciła około 130 tys. wyborców. W wyborach z 2019 roku po raz pierwszy uczestniczył Ruch Nie dla Opłat Drogowych ${ }^{52}$, który na poziomie gminnym uzyskał 2,4 proc. głosów, przy czym w Bergen otrzymał aż 16,9 proc. głosów, a w Oslo - 5,9 proc. $^{53}$.

51 N. Berglund, Counties... .

52 Do zwolenników partii sprzeciwu - Ruchu Nie dla Opłat Drogowych - należą głównie słabo zarabiający mężczyźni, których konsekwencje planowanych proekologicznych zmian dotkną najbardziej. Ibidem.

53 T. Wandzel, Wybory 2019: nowy krajobraz polityczny w Norwegii, Nettavisen, 10 września 2019, https://www.nettavisen.no/oversatt/wybory-2019-nowy-krajobraz-polityczny-w-norwegii/3423843211.html (dostęp: listopad 2020). 
Utraty poparcia w wyborach z 2019 roku dla dotychczasowych liderów partyjnych można upatrywać w tematyce kampanii wyborczej. Debata polityczna koncentrowała się na kwestiach dotyczących klimatu, opłat drogowych i polityki lokalnej. W stosunku do tych zagadnień Partia Pracy i Partia Konserwatywna nie przedstawiały jasnego stanowiska, co mogło wpłynąć na odpływ elektoratu. Przyczyną utraty części głosów były też niepopularne reformy, między innymi wymuszone łączenie gmin, a także reorganizacja sieci posterunków policji i szpitali, co sprawiło, że część mieszkańców ma utrudniony dostęp do usług publicznych. Ponadto doszło do kryzysu rządowego w związku ze sporem o to, czy za utrzymanie i budowę dróg oraz za transport publiczny płacić ze środków pozyskiwanych z opłat nakładanych na kierowców. Słaby wynik Partii Pracy i Partii Konserwatywnej wpisuje się $\mathrm{w}$ tendencje widoczne w innych państwach, w których poparcie uzyskują partie skrajnych skrzydeł lewicowych i prawicowych oraz partie opierające swoją kampanię na wybranym problemie. Wyniki wyborów lokalnych w Norwegii oznaczają zmniejszenie poparcia dla tradycyjnych ugrupowań na rzecz partii protestu oraz partii proekologicznych i lewicowych. Potwierdza to światowe tendencje związane z postępującą polaryzacją i fragmentaryzacją sceny politycznej. Wyborcy kwestionują partyjną oś podziału prawica-lewica. Dotychczasowe poparcie mieszkańców dla dużych partii jest przenoszone na rzecz Zielonych oraz na inne radykalne ruchy po lewej stronie sceny politycznej (w przypadku Norwegii - na Partię Socjalistyczną i Lewicę) $)^{54}$.

Biorąc pod uwagę wpływy partii politycznych, należy stwierdzić, że Norwegia jest wyraźnie podzielona. Partia Konserwatywna może liczyć na najwięcej głosów w regionach bogatych i wysoko zurbanizowanych (Oslo). Partie lewicowe cieszą się popularnością wśród wyborców wschodnich, centralnych i północnych obszarów państwa (na przykład Partia Pracy uzyskuje dobre wyniki w Trøndelag i Troms og Finnmark, Partia Socja-

54 Wybory w Norwegii: Tracq konserwatyści, sukces partii kierowców, Rzeczpospolita, 10 września 2019, https://www.rp.pl/Polityka/190919996-Wybory-w-Norwegii-Traca-konserwatyscisukces-partii-kierowcow.html (dostęp: listopad 2020); M. Kucharczyk, Wybory lokalne w Norwegii. Spadek poparcia dla koalicji rzadowej, Euractiv.pl, 19 września 2019, https://www.euractiv.pl/section/demokracja/news/wybory-lokalne-w-norwegii-spadek-poparcia-dla-koalicji-rzadowej/ (dostęp: wrzesień 2019); T. Wandzel, Wybory 2019... . 
listyczna może liczyć na głosy wyborców w Nordland, Oslo i Trøndelag). Południowe prowincje Norwegii (na przykład Agder) są tradycyjnie obszarem wpływów Partii Chrześcijańskiej. Partia Postępu uzyskuje dużą liczbę głosów w południowo-zachodnich prowincjach przemysłowych (Rogaland, Vestfold og Telemark). Partia Centrum otrzymuje najwyższe poparcie w prowincjach o charakterze rolniczym ${ }^{55}$.

\section{Poparcie kandydatów ze względu na ich płeć, wiek, pochodzenie i wykształcenie}

W wyborach do rad gmin z 2011 roku wśród kandydatów umieszczonych na listach 42 proc. stanowiły kobiety (konsekwencja tak zwanego systemu kwot partyjnych ${ }^{56}$ ), najwięcej w grupach wiekowych 18-29 i 30-39 lat. Wśród mężczyzn przeważali kandydaci po 40. roku życia (44 proc.) i po 60. roku życia (17 proc.). Jedynie Partia Socjalistyczna umieściła na listach wyborczych więcej kobiet (53 proc.) niż mężczyzn (47 proc.). Partia Pracy umieściła na listach 48 proc. kobiet, Chrześcijańska Partia Ludowa - 45 proc., Partia Konserwatywna - 39 proc., a Partia Postępu 29 proc. ${ }^{57}$. W wyborach do rad prowincji udział kobiet na listach wyborczych wynosił 44 proc. i w żadnej z partii nie przekroczył 50 proc. Najwięcej kobiet i osób w przedziale wiekowym 18-29 lat znalazło się na listach wyborczych Chrześcijańskiej Partii Ludowej ${ }^{58}$. Charakteryzując

55 M. Dudzicz, Królestwo..., s. 463.

56 Kobiety są doreprezentowane w organach samorządowych podejmujących decyzje w Norwegii dzięki tak zwanemu systemowi kwot partyjnych, tj. dobrowolnemu przyjęciu przez poszczególne partie polityczne założenia, że układając listy wyborcze, zobowiązują się do uwzględnienia określonego odsetka kobiet. Szerzej: M. Półtorak, A. Kalisz, Kwoty w europejskich systemach wyborczych jako wyraz zasady równości a funkcje prawa, http://www.sbc.org. pl/Content/22127/poltorak_kalisz.pdf (dostęp: lipiec 2020). W Norwegii największe partie polityczne (Partia Pracy, Partia Socjalistyczna, Partia Centrum, i Chrześcijańska Partia Ludowa) wprowadziły wewnętrzne kwoty, to znaczy zarezerwowały $40-50$ proc. miejsc na listach wyborczych dla kobiet. Voluntary Political Party Quotas, Gender Quotas Database, International Institute for Democracy and Electoral Assistance (IDEA), Stockholm, b.d., http://www. quotaproject.org/systemParty.cfm (dostęp: listopad 2020).

57 Most Nominees....

58 Candidates at County Council Election, by Age, Sex and County. 2011, Statistics Norway, b.d., http://www.ssb.no/a/english/kortnavn/kfvalgkand_en/tab-2011-07-01-12-en.html (dostęp: listopad 2020). 
udział imigrantów, należy podkreślić, iż cudzoziemcy stanowili 3,5 proc. kandydatów umieszczonych na listach ${ }^{59}$, najczęściej pochodzili z innych państw skandynawskich, a 49 proc. spośród nich stanowiły kobiety. Około 40 proc. kandydatów miało wyższe wykształcenie, częściej były to kobiety i osoby młode. Najwięcej kandydatów z wyższym wykształceniem zostało zarejestrowanych przez Partię Socjalistyczną (66 proc.), najmniej znalazło się na listach Partii Postępu (14 proc.) ${ }^{60}$.

Analizując wyniki wyborów z 2011 roku z uwzględnieniem płci, wieku i wykształcenia wyłonionych radnych, należy podkreślić, iż w radach gmin i radach prowincji kobiety stanowiły około 38 proc. członków ${ }^{61}$. Biorąc pod uwagę przynależność partyjną, wśród radnych reprezentujących Partię Socjalistyczną znalazło się 51 proc. kobiet, w przypadku radnych z Partii Pracy udział kobiet wynosił 44 proc., najniższy zaś był w Partii Postępu (27 proc.). Imigranci, którym udało się uzyskać mandat stanowili tylko 2,5 proc. wszystkich członków rad gmin i rad prowincji. Najczęściej zasiedli w radach z ramienia Partii Socjalistycznej (5 proc. radnych), Partii Pracy (4 proc.) i Partii Konserwatywnej (2 proc.).

W wyborach z 2011 roku największą grupę radnych stanowili mężczyźni w wieku 40-49 lat (29 proc.) oraz 50-59 lat (26 proc.). Blisko 50 proc. radnych miało wyższe wykształcenie, częściej (55 proc.) były to kobiety. W grupie radnych reprezentujących Partię Socjalistyczną, mimo niewielu zdobytych mandatów, większość radnych (75 proc.) miała wyższe wykształcenie i był to najwyższy wskaźnik spośród

59 Według danych norweskiego Centralnego Urzędu Statystycznego (Statistisk Sentralbyrå) w wyborach z 2011 roku wśród cudzoziemców najliczniej głosowali Holendrzy (56 proc.), a najsłabiej reprezentowaną grupą byli Polacy (8 proc.). Nieco ponad trzech na dziesięciu głosujących obcokrajowców (38 proc.) pochodziło ze Szwecji. Dane statystyczne potwierdzają, że udział w wyborach dla uprawnionych do głosowania cudzoziemców wzrasta wraz z długością okresu zamieszkiwania w Norwegii i na przykład wśród Szwedów mieszkających w Norwegii dłużej niż 30 lat frekwencja wyborcza utrzymuje się na takim samym poziomie jak frekwencja Norwegów. W 2011 roku na reprezentantów do rad gmin wybrano 268 obcokrajowców, tj. 2,5 proc. kandydatów spośród cudzoziemców. Ibidem.

60 Higher Voter...

$61 \mathrm{Z}$ badań nad uczestnictwem grup niedoreprezentowanych w polityce wynika, że aby grupy te miały realny wpływ na podejmowanie decyzji, powinny posiadać 30 proc. członków w organie decyzyjnym. Zob. A. Niżyńska, Kandydatki w wyborach samorzadowych w 2010 roku. Badania, ekspertyzy, rekomendacje, Instytut Spraw Publicznych, Warszawa 2011, s. 4. 
radnych wszystkich partii wybranych w wyborach samorządowych w 2011 roku $^{62}$.

W 2015 roku udział radnych gminnych i radnych prowincji z wyższym wykształceniem w porównaniu z wyborami z 2011 roku osiągnął poziom 50 proc. Liczba cudzoziemców uprawnionych do głosowania systematycznie rosła przy okazji każdych wyborów samorządowych. Można zatem stwierdzić, że następuje wzrost ich zainteresowania udziałem w lokalnym życiu społeczno-politycznym ${ }^{63}$. Wśród imigrantów, którzy otrzymali obywatelstwo norweskie, udział głosujących w wyborach lokalnych wzrósł do 40 proc., a wśród osób bez obywatelstwa, ale z prawem do głosowania - do 29 proc. $^{64}$. W wyniku wyborów z 2015 roku imigranci uzyskali 3 proc. mandatów. Najaktywniejsi wśród głosujących byli uchodźcy ze Sri Lanki i Somalii ${ }^{65}$. Niemal 60 proc. imigrantów pochodzących z Azji, Afryki i Ameryki Południowej (podobnie jak większość Norwegów) głosowało na Partię Pracy ${ }^{66}$.

W 2015 roku odnotowano, w stosunku do poprzednich wyborów, nieznaczny wzrost udziału kobiet, które uzyskały mandaty w radach gmin (z 38 proc. do 39 proc.). Kobiety najczęściej kandydowały z poparcia Partii Pracy i stanowiły aż 57 proc. przewodniczących rad gmin ubiegających się o mandaty z ramienia tego ugrupowania. Najwięcej kobiet otrzymało mandat radnej z listy Partii Socjalistycznej (48 proc.) i Partii Pracy (44 proc.) - w obu przypadkach utrzymana została niewielka tendencja wzrostowa w porównaniu z poprzednimi elekcjami. Wśród mandatów zdobytych w samorządzie przez Partię Postępu kobietom przypadło

62 W Norwegii regularne badania zachowań wyborczych są prowadzone od 1957 roku. Zob. Most Nominees...; A. Kubka, Metodologiczne..., s. 191-204. Podobne badania są prowadzone w innych krajach europejskich.

63 Municipal and County Council Election, Persons Entitled to Vote, Statistics Norway, 13 sierpnia 2019, https://www.ssb.no/en/valg/statistikker/stemmerettkomm (dostęp: listopad 2020).

64 Immigrants and the 2015 Municipal and County Council Elections, Statistics Norway, 3 maja 2017, https://www.ssb.no/en/valg/artikler-og-publikasjoner/immigrants-and-the-2015-municipal-and-county-council-elections (dostęp: listopad 2020).

65 Refugees and Political Participation - Municipal Elections 2015. Do Refugees Get Involved in Local Politics?, Statistics Norway, 23 stycznia 2017, https://www.ssb.no/en/valg/artikler-ogpublikasjoner/do-refugees-get-involved-in-local-politics (dostęp: listopad 2020). 
jedynie 27 proc. $^{67}$. Najwięcej kobiet radnych należało do grupy wiekowej 40-60 lat, natomiast mężczyzn - 45-66 lat ${ }^{68}$. Zwiększył się też procentowy udział kobiet w sprawowaniu funkcji przewodniczących rad (z 22,3 proc. do 28,2 proc.). Udział kobiet zasiadających w zarządach gmin wyniósł 44 proc. Kobiety zostały burmistrzami w 120 gminach (tj. w 28 proc. samorządów), w tym w największych miastach: Oslo, Trondheim i Bergen. W radach prowincji 45 proc. członków stanowiły kobiety, a w zarządach prowincji odsetek ten wynosi $50^{69}$. Kobiety, podobnie jak mężczyźni, najczęściej głosowały na Partię Pracy (37 proc.) i Partię Konserwatywną (22 proc. $)^{70}$.

W związku z reformą konsolidacyjną gmin i prowincji, w wyborach w 2019 r. Norwegowie głosowali na zmniejszoną liczbę samorządowców ${ }^{71}$. W stosunku do poprzednich wyborów nastąpił wzrost udziału kobiet, które uzyskały mandaty (do 40 proc.). Podobnie jak we wcześniejszych wyborach najwięcej kobiet otrzymało mandat radnej z listy Partii Socjalistycznej (54 proc.) i Partii Pracy (46 proc.) - w obu przypadkach utrzymana została niewielka tendencja wzrostowa $\mathrm{w}$ porównaniu z poprzednimi elekcjami. Najmniej kobiet radnych zostało wybranych z list Partii Postępu (26 proc.; spadek w stosunku do poprzedniej elekcji o 1 pkt proc. $)^{72}$. Niemal wszystkie

67 Opracowano na podstawie danych statystycznych norweskiego Centralnego Urzędu Statystycznego, Municipal and County Council Election. Candidates and Representatives, Statistics Norway, 27 lutego 2020, https://www.ssb.no/en/valg/statistikker/kommvalgform (dostęp: listopad 2020).

68 Najwięcej kobiet radnych (aż 68,4 proc.) wybrano w gminie Amot, najmniej (po 17,4 proc.) - w gminach Hjartdal i Hurdal. Zob. Female Chairmen in Three out of Ten Municipalities, Statistics Norway, 28 stycznia 2016, https://www.ssb.no/en/valg/artikler-og-publikasjoner/ female-chairmen-in-three-out-of-ten-municipalities (dostęp: listopad 2020); Women in Local Politics in Norway - Local Election Results 2015, Government.no, 5 lutego 2019, https://www. regjeringen.no/en/topics/kommuner-og-regioner/lokaldemokrati/women-in-local-politics -in-norway/id2605288/ (dostęp: listopad 2020).

69 Female Chairmen...; Women in Local... .

70 Municipal and County Council Election, Electoral Survey, Statistics Norway, 24 marca 2020, https://www.ssb.no/en/valg/statistikker/vundkomm (dostęp: listopad 2020).

71 Regulations for the 2019 Local Government Elections for Municipalities and Counties that are Subject to Boundary Changes that Come into Effect January 1st 2020, Government.no, 20 marca 2019, https://www.regjeringen.no/en/dokumenter/regulations-for-the-2019-local-governmentelections-for-municipalities-and-counties-that-are-subject-to-boundary-changes-that-come -into-effect-january-1st-2020/id2637010/ (dostęp: listopad 2020).

72 Opracowano na podstawie danych statystycznych norweskiego Centralnego Urzędu Statystycznego, Municipal and County Council Election. Candidates and Representatives... . 
partie biorące udział w wyborach lokalnych odnotowały wyższy odsetek kobiet (które odniosły sukces) w grupach wiekowych poczynając od najmłodszych, a kończąc na przedziale 50-59 lat niż w przypadku radnych mężczyzn, których znacząco więcej było w grupie radnych powyżej 60 . roku życia. Odwrotna sytuacja wystąpiła jedynie w przypadku komitetów lokalnych ${ }^{73}$. Kobiety radne najczęściej legitymowały się wykształceniem wyższym (licencjackim, magisterskim) - łącznie 64 proc., w przypadku mężczyzn było to wykształcenie średnie - 46 proc. Kobiety, podobnie jak mężczyźni, najczęściej głosowały na Partię Pracy (26 proc.) oraz Partię Konserwatywną (18 proc.), jednak, w porównaniu z wyborami z 2015 roku, ich poparcie dla tej partii uległo osłabieniu na rzecz komitetów lokalnych oraz Patrii Centrum ${ }^{74}$. Zwiększył się też udział kobiet zajmujących stanowisko przewodniczących rad (z 28 proc. do blisko 35 proc.). Było to związane z wewnętrzną polityką Partii Centrum, w której częściej niż w dwóch poprzednich elekcjach do wskazywanej funkcji proponowane były kobiety ${ }^{75}$.

Tendencja udziału cudzoziemców w wyborach została utrzymana. Nieco ponad 3 proc. przedstawicieli wybranych w 2019 roku do samorządu lokalnego Norwegii stanowi ludność napływowa, głównie osoby pochodzące z Azji, Afryki i Ameryki Łacińskiej. Najwięcej samorządowców-cudzoziemców uzyskało mandaty w dużych miastach, w tym w Oslo ${ }^{76}$. Uwzględniając odsetek zdobytych mandatów, należy stwierdzić, że dużą grupę radnych pochodzących spoza Norwegii wprowadziły Partia Pracy (108 osób, 38 proc.) i Partia Socjalistyczna (39 osób, 14 proc.) ${ }^{77}$.

73 Zob. Municipal and County Council Election, Candidates and Representatives, Statistics Norway, 27 lutego 2020, https://www.ssb.no/en/statbank/table/06538/tableViewLayout1/ (dostęp: listopad 2020).

74 Opracowano na podstawie danych Norweskiego Centralnego Urzędu Statystycznego, Municipal and county Council Election, Electoral Survey... .

75 Opracowano na podstawie danych Norweskiego Centralnego Urzędu Statystycznego, Municipal and County Council Election, Executive Committee of Local Council and Chairman Election, Statistics Norway, b.d., https://www.ssb.no/en/valg/statistikker/kommvalgform (dostęp: listopad 2020).

76 Opracowano na podstawie danych Norweskiego Centralnego Urzędu Statystycznego, Municipal and County Council Election, Candidates and Representatives, 12873: Members of the Municipal Councils, by Region and Country Background 2019, Statistics Norway, b.d., https:// www.ssb.no/en/statbank/table/12873/tableViewLayout1/ (dostęp: listopad 2020).

77 Opracowano na podstawie danych Norweskiego Centralnego Urzędu Statystycznego, Municipal and County Council Election, Candidates and Representatives. 04980: Members of the 


\section{Wnioski}

W norweskiej ugruntowanej demokracji lokalnej funkcjonuje tradycyjny dla państw skandynawskich dwustopniowy model samorządu terytorialnego, który był kilkakrotnie reformowany w celu przystosowania do zmieniających się warunków ekonomicznych, społecznych i demograficznych. Wprowadzane reformy, zwłaszcza po 1992 roku, miały na celu decentralizację, zwiększenie autonomii oraz efektywności działania gmin i prowincji, czemu służyła między innymi reforma konsolidacyjna, która weszła w życie 1 stycznia 2020 roku. W efekcie większe gminy mają szerszą autonomię i zakres działania, zwłaszcza w zakresie pomocy społecznej, skoordynowanego rozwoju społecznego i stabilnego finansowo budżetu, co przekłada się na wzmocnienie demokracji lokalnej ${ }^{78}$.

Zmiany i eksperymentowanie z nowymi rozwiązaniami nie ominęły też procedur wyborczych. W wyborach z 2011 roku po raz pierwszy stworzono możliwość oddania głosu osobom od 16. roku życia. Umożliwiono także głosowanie za pośrednictwem Internetu. Rozwiązanie to, chociaż cieszyło się popularnością, a głosowanie drogą elektroniczną było możliwe również w wyborach parlamentarnych w 2013 roku, nie zostało wpisane na stałe do procedur wyborczych. Norwegowie obawiali się o należyte zachowanie tajności głosowania, co mogłoby nadwyrężyć mechanizmy demokracji. Ponadto, jak pokazały dane statystyczne, głosowanie przy użyciu Internetu, chociaż dość popularne, nie spowodowało zakładanego wzrostu frekwencji wyborczej ${ }^{79}$. W 2019 roku 18 gmin $^{80}$ wprowadziło możliwość rozsyłania cyfrowych wersji kart wyborczych ${ }^{81}$.

Municipal Councils, by Country Background and Party/Electoral List 2003-2019, Statistics Norway, 27 lutego 2020, Statistics Norway, 27 lutego 2020, https://www.ssb.no/en/statbank/ table/04980/tableViewLayout1/ (dostęp: listopad 2020).

78 Local Government Reform to Secure Future Welfare, Government.no, 14 maja 2014, http:// www.regjeringen.no/en/dep/kmd/press/press-releases/2014/Local-government-reform-tosecure-future-welfare.html?regj_oss=1\&id=759493 (dostęp: listopad 2020).

79 Norwegia porzuca gtosowanie przez Internet, Puls Biznesu, 28 czerwca 2014, http://www. pb.pl/3744299,62193,norwegia-porzuca-glosowanie-przez-internet (dostęp: listopad 2020).

80 Były to: Bergen, Bodø, Fredrikstad, Færder, Gjøvik, Gloppen, Grimstad, Hamar, Hå, Lillesand, Skaun, Skien, Stjørdal, Tromsø, Ulstein, Vadsø, Vanylven i Vågan. Zob. M. Zych, Lokalne wybory....

81 Uprawnieni mieszkańcy otrzymali SMS z linkiem do pobrania karty wyborczej. 
W przypadku norweskiej demokracji system wyborczy przyczynia się do aktywności wyborczej obywateli, gdyż jest skonstruowany w taki sposób, aby w strukturach organów władzy samorządowej miały szansę być reprezentowane każda grupa społeczna i każdy komitet wyborczy. Świadczy o tym zarówno możliwość „tworzenia” własnej listy wyborczej poprzez dopisywanie nazwisk na kartach do głosowania, mnogość podmiotów politycznych ubiegających się i uzyskujących mandaty na poziomie gminnym i prowincjonalnym, jak i sposób liczenia głosów oraz podziału miejsc w radach. Obowiązujący w Norwegii system proporcjonalny połączony z możliwością oddania głosu indywidualnego (zasada reprezentacji proporcjonalnej) umożliwia udział w wyborach wielu ugrupowaniom i komitetom lokalnym. Ponadto kobiety we władzach lokalnych mają na tyle dużą reprezentację, że wywierają realny wpływ na podejmowane decyzje. System wyborczy nie wyklucza także cudzoziemców, którzy, po spełnieniu określonych wymagań, posiadają bierne i czynne prawa wyborcze. W ten sposób skonstruowany samorząd odsuwa na drugi plan podziały partyjne, ugruntowując idee społeczne w realizacji zadań lokalnych.

Rozwiązania norweskie stanowią przykład wyraźnie widocznych procesów społecznych. Imigranci i cudzoziemcy w konsekwencji kolejnych wyborów uzyskują poparcie i tym samym reprezentacje w radach, zwłaszcza w dużych miastach. Rosnące zainteresowanie kobiet biernym prawem wyborczym przekłada się na ich udział w samorządach lokalnych na różnych stanowiskach. Aktywność ta sprawia, że władze lokalne są bardziej otwarte na problemy społeczne i współpracę z organizacjami, realizując założenia państwa opiekuńczego. Wysoki odsetek kobiet w samorządach przyczynia się do sprawnego funkcjonowania państwa opiekuńczego na poziomie lokalnym. Jak wynika z badań, kobiety są bardziej niż mężczyźni wrażliwie na kwestie społeczne i socjalne, a podczas podejmowania decyzji w większym stopniu uwzględniają czynnik ludzki ${ }^{82}$. W Norwegii bardzo sprawnie działa opieka nad seniorami i dziećmi, co umożliwia kobietom pracę zarobkową. Ponadto duży odsetek kobiet w samorządach (zarówno

82 Por. J. Wasil, Local Leadership of Women in Local Government in Rural Areas in Poland, w: A. Azevedo, A. Mesquita (red.), Proceedings of the International Conference on Gender Research, Porto 2018, s. 474. 
w radach, jak i w zarządach) - wymuszony parytetem - „otwiera” gremia decyzyjne na kwestie społeczne, problematykę seniorów, edukacji czy integracji mniejszości narodowych. Dodatkowo uwzględniając głosy mniejszości narodowych i cudzoziemców, można stwierdzić, że to ten segment wyborców doprowadza do zapewnienia zwycięstwa Patii Pracy, choć poparcie zarówno dla tego ugrupowania, jak i dla innych pozostających na norweskiej scenie politycznej, w ostatnim dziesięcioleciu zmalało.

W Norwegii tworzenie i funkcjonowanie samorządu lokalnego postrzega się jako emanację wspólnoty lokalnej i podstawowy wyraz społeczeństwa obywatelskiego, a nie instytucjonalnej organizacji najniższego poziomu administracji państwowej. Poszerzone grono wyborców pozwala na różnorodność - zarówno w zakresie artykułowania potrzeb (ludzi młodych, cudzoziemców), jak i realizowania pomysłów na rozwój lokalnego środowiska.

\section{Bibliografia}

10 per cent of Eligible Voters Have Immigrant Background, Statistics Norway, 24 sierpnia 2016, http://www.ssb.no/en/valg/statistikker/stemmerettkomm. Act no. 57 of 28 June 2002 relating to parliamentary and local government elections, Government.no, 14 marca 2019, https://www.regjeringen.no/en/dokumenter/election-act/id2632557/.

Baldersheim H., Saglie J., Bock Segaard S., Internet Voting in Norway 2011: Democratic and Organisational Experiences, Den XXI Nordiske Kommuneforskingskonferansen, Universitetet i Oslo, Oslo 2012.

Baldersheim H., Samorzady lokalne krajów skandynawskich $w$ okresie przejściowym: od wolnych gmin do wolnego wyboru? Nowy program reform samorzadowych w państwach skandynawskich, „Samorząd Terytorialny” 1994, nr 1-2.

Barrat Esteve J., Goldsmith B., Turner J., Speed and Efficiency of the Vote Counting Process. Norwegian e-Vote Project, The International Foundation for Electoral Systems (IFES), Washington D.C., lipiec 2012, dostępne na: http://www.regjeringen.no/upload/KRD/Prosjekter/e-valg/evaluering/Topic4_Assessment.pdf.

Berbeć M, Historyczne zmiany na mapie Norwegii: rzad połaczy część norweskich gmin... sita, Moja Norwegia. Portal Polaków w Norwegii, 2 czerwca 2017, https://www.mojanorwegia.pl/aktualnosci/historyczne-zmiany-namapie-norwegii-rzad-polaczy-czesc-norweskich-gmin-sila-12891.html. 
Bereza-Jarociński A., Zarys dziejów Norwegii, Wydawnictwo Naukowe PWN, Warszawa 1991.

Berglund M., Counties Will be Forced to Merge, NewsinEnglish.no, 24 sierpnia 2018, https://www.newsinenglish.no/2018/09/24/counties-will-be-forcedto-merge/.

Berglund N., Small Towns Want to Stay That Way, NewsinEnglish.no, 24 maja 2016, https://www.newsinenglish.no/2016/05/24/residents-reject-municipal-mergers/.

Candidates at County Council Election, by Age, Sex and County. 2011, Statistics Norway, b.d., http://www.ssb.no/a/english/kortnavn/kfvalgkand_en/tab2011-07-01-12-en.html.

Cieślak T., Norwegia. Z dziejów XIX i XX wieku, Wydawnictwo Poznańskie, Poznań 1970.

Cieślak T., Zarys historii najnowszej krajów skandynawskich, Wydawnictwo Naukowe PWN, Warszawa 1978.

Dudzicz M., Królestwo Norwegii, w: S. Wróbel (red.), Samorząd terytorialny państw europejskich, Wydawnictwo Śląsk, Katowice 2012.

Electoral Turnout, Statistics Norway, 8 października 2019, https://www.ssb.no/ en/valg/statistikker/valgdeltakelse.

Female Chairmen in Three out of Ten Municipalities, Statistics Norway, 28 stycznia 2016, https://www.ssb.no/en/valg/artikler-og-publikasjoner/femalechairmen-in-three-out-of-ten-municipalities.

Gminy nie chca się taczyć, ale... rzad może je do tego zmusić, Moja Norwegia. Portal Polaków w Norwegii, 8 września 2016, https://www.mojanorwegia. $\mathrm{pl}$ /polityka/gminy-nie-chca-sie-laczyc-ale-rzad-moze-je-do-tego-zmusic-11864.html.

Grzybowski M., Norwegia. Zarys systemu ustrojowego, Wydawnictwo Uniwersytetu Jagiellońskiego, Kraków 2015.

Grzybowski M., Organizacje interesów grupowych $i$ ich rola w szwedzkim $i$ norweskim systemie politycznym, „Zeszyty Naukowe Uniwersytetu Jagiellońskiego. Prace z Nauk Politycznych" 1984, t. 21.

Grzybowski M., Rzad $i$ administracja rzadowa $w$ monarchiach skandynawskich (Dania - Norwegia - Szwecja), Oficyna Wydawnicza Abrys, Kraków 2001.

Grzybowski M., Systemy konstytucyjne państw skandynawskich, Wydawnictwo Sejmowe, Warszawa 1998.

Higher Voter Turnout, Statistics Norway, 22 sierpnia 2014, http://www.ssb.no/ en/valg/statistikker/kfvalgkand.

Immigrants and the 2015 Municipal and County Council Elections, Statistics Norway, 3 maja 2017, https://www.ssb.no/en/valg/artikler-og-publikasjoner/immigrants-and-the-2015-municipal-and-county-council-elections. 
Kaczmarek T., Struktury terytorialno-administracyjne $i$ ich reformy $w$ krajach europejskich, Wydawnictwo Naukowe Uniwersytetu Adama Mickiewicza, Poznań 2005.

Konstytucja Królestwa Norwegii, tłum. J. Osiński, Wydawnictwo Sejmowe, Warszawa 1996.

Kubka A. Modele demokracji w Skandynawii, Wydawnictwo Libron, Kraków 2016.

Kubka A., Demokracja bezpośrednia w Szwecji i Norwegii, w: M. Marczewska-Rytko (red.), Stan i perspektywy demokracji bezpośredniej w Polsce, Wydawnictwo Uniwersytetu Marii Curie-Skłodowskiej, Lublin 2010.

Kubka A., Metodologiczne aspekty badań zachowań wyborczych w Norwegii, w: A. Antoszewski, A. Dumała, B. Krauz-Mozer, K. Radzik (red.), Teoretyczne $i$ metodologiczne wyzwania badań politologicznych w Polsce, Wydawnictwo Uniwersytetu Marii Curie-Skłodowskiej, Lublin 2009.

Kubka A., Partie $i$ systemy partyjne Szwecji, Norwegii $i$ Danii na przełomie XX i XXI wieku, Wydawnictwo Uniwersytetu Gdańskiego, Gdańsk 2009.

Kubka A., Podziaty socjopolityczne w Norwegii w latach 1973-1997, Wydawnictwo Uniwersytetu Gdańskiego, Gdańsk 2004.

Kubka A., Poszukiwanie nowych form demokracji bezpośredniej w krajach skandynawskich, w: M. Marczewska-Rytko (red.), Stan i perspektywy demokracji bezpośredniej we wspótczesnym świecie, Wydawnictwo Uniwersytetu Marii Curie-Skłodowskiej, Lublin 2011.

Kucharczyk M., Wybory lokalne w Norwegii. Spadek poparcia dla koalicji rzadowej, Euractiv.pl, 19 września 2019, https://www.euractiv.pl/section/demo$\mathrm{kracja} / \mathrm{news} /$ wybory-lokalne-w-norwegii-spadek-poparcia-dla-koalicjirzadowej/.

Liber M., Samorzad miejski w Norwegii na przykładzie Oslo, Bergen i Stavanger, w: S. Wróbel (red.), Samorzad miejski - zadania, instytucje, formy, Wydawnictwo Wyższej Szkoły Bankowej, Poznań - Chorzów 2008.

Local Government Act 2001 Revised, updated to 16 April 2019, http://revisedacts.lawreform.ie/eli/2001/act/37/revised/en/pdf?annotations=true.

Local Government Act no. 107 of 25 September 1992, Government.no, 15 listopada 2012, https:/www.regjeringen.no/globalassets/upload/krd/vedlegg/ komm/internasjonalt/local_government_act.pdf (ze zmianami z 2005 i 2012 roku).

Local Government in Norway, Ministry of Local Government and Modernisation, Oslo, b.r.w.

Local Government in Norway, Ministry of Local Government and Regional Development, Oslo 2008. 
Local Government Reform to Secure Future Welfare, Government.no, 14 maja 2014, http://www.regjeringen.no/en/dep/kmd/press/press-releases/2014/Local-government-reform-to-secure-future-welfare.html?regj_oss=1\&id=759493.

Logo J.M., Civil Society and the Welfare State in Norway - Historical Relations and Future Roles, „Community Development Journal” 2018, nr 53 (3).

Most Nominees are Men above 40, Statistics Norway, 1 lipca 2011, http://www. ssb.no/en/valg/statistikker/kfvalgkand.

Municipal and County Council Election, Candidates and Representatives, 12873: Members of the Municipal Councils, by Region and Country Background 2019, Statistics Norway, https://www.ssb.no/en/statbank/table/12873/tableViewLayout1/.

Municipal and County Council Election, Candidates and Representatives, 04980: Members of the Municipal Councils, by Country Background and Party/Electoral List 2003-2019, Statistics Norway, b.d., https://www.ssb.no/en/statbank/table/04980/tableViewLayout1/.

Municipal and County Council Election, Electoral Survey, Statistics Norway, 24 marca 2020, https://www.ssb.no/en/valg/statistikker/vundkomm.

Municipal and County Council Election, Executive Committee of Local Council and Chairman Election, Statistics Norway, b.d., https://www.ssb.no/en/ valg/statistikker/kommvalgform.

Municipal and County Council Election, Persons Entitled to Vote, Statistics Norway, 13 sierpnia 2019, https://www.ssb.no/en/valg/statistikker/stemmerettkomm.

Municipal and County Council Election. Candidates and Representatives, Statistics Norway, 27 lutego 2020, https://www.ssb.no/en/valg/statistikker/ kommvalgform.

Municipal Council Elections and County Council Election 1999-2011. Percentage Voter Turnout in Municipalities With e-Elections, Statistics Norway, 11 listopada 2011, http://www.ssb.no/a/english/kortnavn/kommvalg_en/ tab-2011-11-04-13-en.html.

Niżyńska A., Kandydatki w wyborach samorzadowych w 2010 roku. Badania, ekspertyzy, rekomendacje, Instytut Spraw Publicznych, Warszawa 2011.

Norwegia porzuca głosowanie przez Internet, Puls Biznesu, 28 czerwca 2014, http://www.pb.pl/3744299,62193, norwegia-porzuca-glosowanie-przez-internet (dostęp: listopad 2020).

Nowacka E.J., Samorzad terytorialny jako forma decentralizacji administracji publicznej, LexisNexis, Warszawa 2010. 
Nowiak W., Stopniowe usamodzielnianie finansowe społeczności lokalnych Norwegii. Element upodmiotowienia społeczeństwa dobrobytu, w: D. Walczak-Duraj (red.), Tradycja $i$ wspótczesne odmiany samorzadności, „Zeszyty Naukowe Szkoły Wyższej im. Pawła Włodkowica w Płocku" 1999, t. 11.

Osiński J., Doświadczenia samorzadu lokalnego w krajach nordyckich a reforma samorzadowa w Polsce, w: P. Dobrowolski (red.), Władza i spoteczności lokalne a reforma samorzadowa w Polsce, Wydawnictwo Uniwersytetu Śląskiego, Katowice 1995.

Osiński J., Parlament i rzad w Królestwie Norwegii, Szkoła Główna Handlowa, Warszawa 1994.

Osiński J., Problemy aksjologii samorządności lokalnej w krajach nordyckich $i w$ Polsce, w: B. Nawrot, J. Pokładecki (red.), Samorzad gminny w Polsce. Stan obecny i perspektywy, Wydawnictwo Naukowe Uniwersytetu Adama Mickiewicza, Poznań 1999.

Osiński J., Status i funkcjonowanie samorzadu lokalnego w państwach skandynawskich, w: D. Walczak-Duraj (red.), Tradycja $i$ wspótczesne odmiany samorzadności, „Zeszyty Naukowe Szkoły Wyższej im. Pawła Włodkowica w Płocku" 1999, t. 11.

Półtorak M., Kalisz A., Kwoty w europejskich systemach wyborczych jako wyraz zasady równości a funkcje prawa, http://www.sbc.org.pl/Content/22127/ poltorak_kalisz.pdf.

Rajca L., Modele samorzadu terytorialnego, w: L. Rajca (red.), Samorzad terytorialny w Europie Zachodniej, Wydawnictwo Elipsa, Warszawa 2010.

Refugees and Political Participation - Municipal Elections 2015. Do Refugees Get Involved in Local Politics?, Statistics Norway, 23 stycznia 2017, https:// www.ssb.no/en/valg/artikler-og-publikasjoner/do-refugees-get-involvedin-local-politics.

Regulations for the 2019 Local Government Elections for Municipalities and Counties that are subject to Boundary Changes that Come into Effect January 1st 2020, Government.no, 20 marca 2019, https://www.regjeringen.no/ en/dokumenter/regulations-for-the-2019-local-government-elections-for -municipalities-and-counties-that-are-subject-to-boundary-changes-thatcome-into-effect-january-1st-2020/id2637010.

Regulations on the Implementation of the County Council Elections in 2019, Ministry of Local Government and Modernisation, Oslo, 2 maja 2018 31 grudnia 2019.

Saglie J., Sivesind K.H., Civil Society Institutions or Semi-public Agencies? State Regulation of Parties and Voluntary Organizations in Norway, „Journal of Civil Society" 2018, t. 14, nr 4. 
Sześciło D., Jakubek-Lalik J., Zróżnicowanie systemów wyborczych w wyborach lokalnych w Europie, w: J. Wojnicki (red.), Europejskie modele samorzadu terytorialnego. Stan obecny i perspektywy, Oficyna Wydawnicza ASPRA-JR, Warszawa 2014.

The Trial of Reducted Voting Age to 16 for the Local Election in 2015, Statistics Norway, b.d., http://www.regjeringen.no/en/dep/kmd/information-campaigns/election_portal/trial-of-reduced-voting-age-to-16-for-th.html?regj_oss=2\&id=581646.

Voluntary Political Party Quotas, Gender Quotas Database, International Institute for Democracy and Electoral Assistance (IDEA), Stockholm, b.d., http://www.quotaproject.org/systemParty.cfm.

Wandzel T., Wybory 2019: nowy krajobraz polityczny w Norwegii, Nettavisen, 10 września 2019, https://www.nettavisen.no/oversatt/wybory-2019-nowy -krajobraz-polityczny-w-norwegii/3423843211.html.

Wasil J., Czynniki ksztattujące frekwencje wyborczą, w: K. Kuć-Czajkowska, K. Efner (red.), Społeczeństwo obywatelskie Lublina $i$ Wroctawia - studia przypadków, Wydawnictwo Uniwersytetu Marii Curie-Skłodowskiej, Lublin 2013.

Wasil J., Local Leadership of Women in Local Government in Rural Areas in Poland, w: A. Azevedo, A. Mesquita (red.), Proceedings of the International Conference on Gender Research, Porto 2018.

Women in Local Politics in Norway - Local Election Results 2015, Government. no, 5 lutego 2019, https://www.regjeringen.no/en/topics/kommuner-ogregioner/lokaldemokrati/women-in-local-politics-in-norway/id2605288.

Wybory w Norwegii: Tracą konserwatyści, sukces partii kierowców, Rzeczpospolita, 10 września 2019, https://www.rp.pl/Polityka/190919996-Wybory-wNorwegii-Traca-konserwatysci-sukces-partii-kierowcow.html.

Zych M., Lokalne wybory po norwesku, czyli jak $i$ gdzie oddać swój głos, Moja Norwegia. Portal Polaków w Norwegii, 27 sierpnia 2019, https://www. mojanorwegia.pl/polityka/lokalne-wybory-po-norwesku-czyli-jak-i-gdzie -oddac-swoj-glos-wybory-2019-16194.html. 


\section{Local Elections in Norway. Example of Citizenship in Well-established Democracy}

The main aim of this paper is to present the issues concerning local elections in Norway. The following timeframe was adopted: from the date of passing the first bill on local government (1837), to the comprehensive description of the municipal and provincial elections held in 2011, 2015, 2019. The electoral system for Norwegian local government allows all social groups and local electoral committees to be represented in local government. This is proved by: the ability to 'create' their own electoral registers by adding new names on ballots, a large number of political entities seeking mandates, the way of counting votes and the distribution of seats in councils. The proportional system of counting votes in Norway (applying the modified Sainte-Laguë method) is connected with the opportunity to cast an individual vote (the principle of proportional representation). This solution enables numerous political groups and local committees to stand for election. Moreover, women have a sufficient representation in local governments to exert a real impact on the decision-making process. Such an electoral system is open to foreigners who, after fulfilling specific requirements, have the right to vote and be elected.

\section{Keywords:}

Norway, LoCAL governMENT, LOCAL ELECTIONS. 